\title{
Günther Anders' Undiscovered Critical Theory of Technology in the Age of Big Data Capitalism
}

\author{
Christian Fuchs \\ University of Westminster, christian.fuchs@uti.at
}

\begin{abstract}
Günther Anders (1902-1992) was an Austrian philosopher, critical theorist, political activist, and a writer of poems, short stories and novels. His works on the critical theory of technology have remained rather undiscovered. His main work Die Antiquiertheit des Menschen (The Antiquatedness of the Human Being) appeared in two volumes and has thus far not been published in English. This essay reviews key aspects of Anders' works and uses them to critically assess big data capitalism. It first discusses Anders' concept of the Promethean gap; the gap between what humans can produce with the help of technologies and the capacity of imagining the negative effects these technologies can have. The essay also engages with Anders' analysis of commercial television and radio. Anders sees capitalism as having catastrophic potentials. He argues that Auschwitz and Hiroshima are two symbols of 20th-century catastrophism. The article discusses Anders' letter to Klaus Eichmann, the son of Adolf Eichmann, who was in charge of the organisation of the displacement and deportation of Jews in the Third Reich. It furthermore analyses the exchange of letters between Anders and Claude Eatherly, the pilot of an aircraft that supported dropping the nuclear bomb "Little Boy" on Hiroshima. Finally, the paper engages with Anders' critique of Martin Heidegger's philosophy. In the age of the Internet and big data capitalism, Anders' warnings about the potential negative effects of capitalist technologies and capitalism remain of crucial relevance and have taken on new qualities. Anders' philosophy is an undiscovered critical theory of technology that allows us to critically understand power structures in the age of big data and social media.
\end{abstract}

Keywords: Günther Anders, critical theory, philosophy of technology, Internet, big data capitalism, social media, Promethean gap, ideology, antiquatedness of the human being, outdatedness, obsolescence, Martin Heidegger

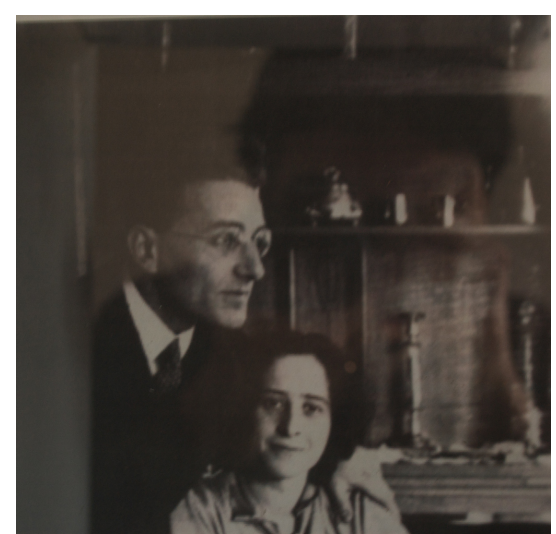

Günther Anders and Hannah Arendt. Source: posted on Flickr as CC by acido nucleio, https://www.flickr.com/photos/guntheranders/4248063814 


\section{Introduction}

Günther Anders (1902-1992) was an Austrian philosopher, critical theorist, political activist, and a writer of poems, short stories, novels, letters, diaries, and short stories. He studied art, history and philosophy in Hamburg, Freiburg and Marburg. His teachers included Edmund Husserl, Martin Heidegger, and Ernst Cassirer. He defended his dissertation in 1923 at the University of Freiburg. Husserl was his PhD supervisor. Just like Herbert Marcuse, Anders turned against his former teacher Martin Heidegger because of the latter's role in the Nazi regime (for a comparison of Anders' and Marcuse's works, see Fuchs 2002). Anders published texts against Heidegger, arguing that his former teacher's philosophy was pseudo-concrete. Anders was married to Hannah Arendt from 1929 until 1937.

As a son of Jewish parents, Anders, like his second cousin Walter Benjamin, had to flee from Germany after Hitler had come to power in 1933. He went first to Paris and then to the USA. The rise of Hitler, Auschwitz, and the dropping of atom bombs on Hiroshima and Nagasaki were politically formative events for Anders that he reflected in his writings. In 1950, Anders and his then-wife Elisabeth Freundlich returned to Europe. They married and settled in Vienna where he lived until his death in 1992.

In distinction to the Frankfurt School critical theorists, Anders explicitly called himself a critical theorist of technology. In his principal work Die Antiquiertheit des Menschen, he studied the transformations of the soul in the age of the second industrial revolution. The German version of the two-volume work consists of 818 pages. The book has until this day not been published in English. The title can be translated as The Antiquatedness of the Human Being, The Outdatedness of the Human Being, or The Obsolescence of the Human Being.

Anders $(1980 \mathrm{a}, 9)$ characterises his approach explicitly as "philosophy of technology". Other critical theorists, such as Herbert Marcuse, also wrote about technology, but did not devote entire books to such analysis and did not define their approaches as critical theory of technology. So Anders' approach is special in that he devoted a lot of attention to the critical analysis of technology's role in society. Anders argued that there are contradictions in society that shape technology and its use (Ibid. 126). He opposed the blind belief in technological progress as well as scepticism towards all technology. A dialectical philosophy of technology has "to discover and determine the dialectical point at which our 'yes' to technology has been transformed into scepticism or into a straightforward 'no'”' (Anders 1980b).

Günther Anders' "genuine interest in different aspects of what he analyses as a global issue of power abuse and repression [...] established him as a transnational intellectual" (Molden 2014, 69). Konrad Paul Liessmann characterises Anders as philosophy's outsider: Anders was a truly interdisciplinary thinker, who wrote "poems, novels, fables and tales as well as philosophical essays and treatises" (Liessmann 2014, 73). Transcendence was a key feature of Anders' works, as he "did not want to commit himself: neither to a provenance, nor to a future; neither to a style, nor to a genre; neither to a philosophical school, nor to an ideology; neither to an institution, nor to an identity; neither to a discipline, nor to a category" (Liessmann 2014, 73).

Anders $(1956,8)$ characterises his philosophy as occasional philosophy: It takes political and other events as occasions for philosophical intervention. Exaggeration is

1 „den dialektischen Punkt ausfindig zu machen und zu bestimmen, wo sich unser Ja der Technik gegenüber in Skepsis oder in ein unverblümtes Nein zu verwandeln hat" (Anders 1980a, 127). 
one of his philosophical methods $(1956,15)$. Anders (1980a, 411-414) says that his writings do not form a system and that Hegel worked out the last systematic philosophy. Because of a lack of translation of his works into English, Günther Anders remains one of the undiscovered critical theorists of society and technology. This essay is an introduction to Anders' main works. It asks: How did Günther Anders analyse modern technology? In which respects does his thought remain relevant in digital capitalism?

The paper proceeds by discussing the relevance of Anders' concept of the Promethean gap (section 2), his analysis of broadcasting (section 3), Auschwitz and Hiroshima as modern catastrophes (section 4), and his criticism of Martin Heidegger's philosophy (section 5 ).

\section{The Promethean Gap}

Günther Anders argues that contemporary society is a system of machines: "The machine system is our 'world"'” (Anders 1956, 2). In this world, we encounter what he (Ibid., 16) terms the Promethean gap, an asynchronicity of humans and products. The Promethean gap entails gaps between the relations of production and ideology, production and imagination, doing and feeling, knowledge and conscience, the machine and the body (Ibid., 18), production and needs (Ibid., 19). We are unable to imagine the vast negative consequences that contemporary technologies' uses can bring about. In the case of catastrophes induced by technologies, we are unable to show grief and remorse because the number of deaths and the extent and intensity of devastation are so excessive.

\subsection{Prometheus}

The Greek myth of Prometheus appears in Theogony (Hesiod 2006), which is a poem by Hesiod, who lived around the time of the $8^{\text {th }}$ and $7^{\text {th }}$ century BC. Prometheus challenges Zeus' power by tricking him into choosing an inferior gift that looks like a superior one. He furthermore steals fire from Mount Olympus and gives it to the humans. Zeus, the king of the gods, unleashes his anger against Prometheus by eternal punishment. Prometheus is chained to a rock and every day an eagle eats up his liver. The liver is restored overnight so that the whole procedure repeats itself daily. Finally, Heracles frees Prometheus. In this myth, Prometheus gives fire to the humans as a means of production because he thinks it emancipates them. But Zeus' wrath is more powerful than Prometheus, whose deed is eternally punished. The attempt of emancipation ends up in suffering, failure and domination. Anders applied the myth of Prometheus as an allegory of modern technology that was first created for emancipating humanity from scarcity and hardship, but has unleashed new destructive powers. We can think of the fire in the Prometheus myth as a symbol of technological progress, while Prometheus' eternal punishment is equivalent to technology and society's negative dialectic that turns against progress and has negative impacts.

The Promethean gap means a "confusion of creator and creation"3 (Anders 2016, 31 [German: Anders 1956, 25]). When "feeling 'Promethean shame' humans also prefer what was made over the maker"4 (Anders 2016, 31 [G: Anders 1956, 25]).

\footnotetext{
${ }^{2}$ Translation from German: „Das Gerätesystem ist unsere, Welt"“.

${ }^{3}$ Translation from German: "Vertauschung von Macher und Gemachtem“.

${ }^{4}$ In German original: „auch in seiner ,promethischen Scham' zieht der Mensch ja das

Gemachte dem Macher vor".
} 
Taking up Marx's notion of alienation and Lukács' concept of reification, Anders argues that there are three stages of reification:

1. The loss of human control of the means of production;

2. "Thing-shame", the human feeling of "shame at not being a thing"5 (Anders 2016, 35 [G: 1956, 30]);

3. Humans' feelings of inferiority to the machine, the "self-degradation in front of fabricated things"" (Anders 2016, 35 [G: 1956, 30]).

When Anders says that humans desert to the camp of the machines (2016, 36 [G: 1956, 31]), he means that ideology "inverts the relation between freedom and unfreedom" (2016, 38 [G: 1956, 33]). Humans who adhere to this ideology think that things "are free and human beings are unfree"" (2016, 38 [G: 1956, 33]).

\subsection{Technological Fetishism}

As an example of technological fetishism, Anders (2016, 58-62 [G: 1956, 59-64]) tells the story of Douglas MacArthur who was UN commander in the Korean War. MacArthur fed data into a computer in order to calculate whether the US should intervene in Korea or not. As all computers used for instrumental reasons, the machine was exclusively fed "with the type of data that did not offer any resistance to quantification" (2016, 59 [G: 1956, 61]). Data and computing cannot make moral judgements because only humans have moral capacities. Questions about "the annihilation of human lives or the devastation of countries" were reduced to "figures of profit or loss"10 $(2016,60$; [G: 1956, 61]) - moral qualities were reduced to calculable quantities. A key decision about life and death was left to a machine.

In Capital Volume 1 (1867), Marx describes in the chapter Machinery and Large Scale Industry (see Fuchs 2016, chapter 15) how capitalist technology's rise was associated with an inversion of means and ends so that humans became a means exploited with the help of machinery for the end of capital accumulation. The "automaton itself is the subject, and the workers are merely conscious organs, coordinated with the unconscious organs of the automaton, and together with the latter subordinated to the central moving force" (Marx 1867, 544-545). Anders describes a state of the world in which alienation not just takes place in the factory and the office, but also at a global scale so that the human world is turned into a machine that instrumentalises (almost) all human activity.

In chapter 1.4 of Capital, Marx $(1867,163-177)$ introduces the notion of commodity fetishism. In capitalism, social relations are not immediately visible to humans, but are veiled and naturalised by the commodity form. We perceive the world as being made up by commodities and do not see how labour produces these commodities. Anders argues that advanced reification results in a worldwide form of reification and reified consciousness so that human alienation is not just a matter of non-control,

\footnotetext{
${ }^{5}$ In German original: „Scham, kein Ding zu sein“.

${ }^{6}$ In German original: „Selbsterniedrigung vor Selbstgemachtem“.

${ }^{7}$ In German original: "die Subjekte von Freiheit und Unfreiheit sind ausgetauscht".

${ }^{8}$ In German original: „Frei sind die Dinge: unfrei ist der Mensch“.

${ }^{9}$ In German original: „mit solchen Daten, die einer Quantifizierung keinen Widerstand entgegensetzten“.

${ }^{10}$ In German original: „was natürlich automatisch zur Folge hatte, daß (zum Beispiel) die Vernichtung von Menschenleben oder die Verwüstung von Ländern, aus methodischen Sauberkeits- und Eindeutigkeitsgründen nur als Profit- oder Verlustgrößen eingesetzt und bewertet werden konnten“.
} 
blindness, and disregard, but also one of love: humans love things that are used to control, dominate and exploit them.

Apocalyptic technologies such as the atom bomb explode the means-ends relationship (Anders 1956, 247-351). They are not means (to ends such as production, exploitation, or victory over an enemy), but destroy all ends by having the potential to annihilate humanity. But if there can be no ends, then there are no means to an end. The nuclear bomb is rather the ultimate meanness that has the potential to terminate humanity. In contemporary capitalism, humans are turned into resources, which is why Anders (1980a, 21) speaks of the homo materia and says that today "being is being-raw-material"11 $(1980 \mathrm{a}, 33)$.

The optimistic version of technological determinism (technological optimism) is an ideology that corresponds to the love and worship of the machine that Anders criticises. Technological determinism considers machines as autonomous actors that determine the development of society. In technological optimism, it is argued that machines result in positive developments of society. In technological pessimism, it is argued that they bring about or strengthen negative features of society. In digital determinism, digital technologies such as the computer, the Internet, web platforms, data, the mobile phone, etc. are treated as fetish objects that are said to determine society's development. For Anders, technology and society stand in a dialectical relationship so that society shapes and is objectified in technology and technology shapes society. Technology is for Anders not a neutral thing that can have different effects depending on its contexts of use. He rather stresses that the social production of technology results in ingrained objective qualities that can unfold complex dynamics and contradictions in society when technologies are used and institutionalised. In a contradictory society, it is likely that we will find contradictory technologies that have contradictory effects on society that cannot be fully predicted.

\subsection{Big Data Fetishism}

Today, ideologues argue that big data is a new technological revolution that changes everything. An example: The "world of big data is poised to shake up everything from businesses and the sciences to healthcare, government, education, economics, the humanities, and every other aspect of society" (Mayer-Schönberger and Cukier 2013, 11). "The benefits to society will be myriad, as bid data becomes part of the solution to pressing global problems like addressing climate change, eradicating disease, and fostering good governance and economic development" (Mayer-Schönberger and Cukier 2013, 17).

Wired Magazine is one of the publications at the forefront of spreading the ideology of optimistic digital determinism. Wired and similar neoliberal magazines like The Economist celebrate the "big data revolution":

- Wired for example reported that big data could cure cancer: "In fields like genetics, neuroscience, and cancer biology, we've built tools that have enabled us to acquire mountains of data. [...] associate professor of systems biology at the University of Cambridge, and senior researcher at Cambridge's Microsoft Research Lab, Fisher is mastering machine power to solve one of our biggest chronic health threats: cancer. Her research relies on the vast amounts of available data on cell biology, generated over the last several decades and plugged into computers to produce models that mimic how cancer cells behave.

\footnotetext{
${ }^{11}$ Translation: „Sein ist Rohstoffsein“.
} 
[...] The more data that's factored in, the higher-resolution the models become, allowing better and quicker predictions about cell behaviour" (Bryce 2017).

- The Economist in an issue with the front-page headline "The world's most valuable resource: Data and the new rules of competition" sees data as "the oil of the digital era" (The Economist, May 6, 2016, p. 9). "Data are to this century what oil was to the last one: a driver of growth and change" (p. 17).

- Wired claimed that big data will boost productivity in general and agricultural productivity in particular: "The UK should invest much more in agricultural R\&D if it is to guarantee its food security. Productivity in UK agriculture has been relatively static for the last ten years. [...] Now, just as the green revolution was based on a change in plant genetics, a new data-led revolution is needed to ensure that productivity continues to grow in a sustainable and resilient way" (Tiffin 2015).

- Another Wired claim was that big data in smart cities would result in overcoming urban problems: "Known as Bristol is Open, the project will effectively turn Bristol into a giant laboratory and look at how big data can be used to solve problems such as air pollution, traffic congestion and assisted living for the elderly. [...] Sensors and other internet of things devices will be hooked up to the network to collect huge amounts of data from the city" (Temperton 2015).

- Quantifying the human self with big data devices would personalise health care as well as prevent and cure illnesses: "we've [...] seen an explosion of various wearables, apps and digital health devices [...] Smartwatches regularly capture heart rate, and soon may add cuffless continuous blood pressure monitoring and glucose measures. [...] Integrated home diagnostic 'medical Tricorder' platforms and connected pill bottles are coming to market. These will be paired with Amazon Echo and Your.MD and similar healthcare chatbots as interfaces. Mental health can be discerned from analysing our speech and the 'digital exhaust' from our smartphones. Breath can be analysed for more than alcohol, to track hydration status and molecules that can indicate a metabolic or malignant disease. Sensors in our beds can readily track the quantity and quality of sleep. Connected onesies or sensor-fitted pacifiers can track the vitals and activity of our newborns. [...] Increasingly, software will check and parse the data from these streams to help identify trends and alert the patient and their care teams much earlier. Startups such as Sentrian (founded by Harley Street physician Jack Kreindler) are making sense of remote patient data to decrease preventable hospital admissions by making predictions, alerting patients and caregivers to act early in the course of changes or deterioration. [...] The quantification of health will have true uses, can be crowdsourced and shared, and will improve outcomes (and perhaps even lower costs) across healthcare" (Kraft 2017).

- Big data would prevent social unrest and terrorism: Big data can "pick up where the next bout of social unrest will appear in the Middle East, or reveal a new history of the US Civil War [...] news mining can track changes in the public discourse that might foreshadow social unrest" (Steadman 2013)

- Big data algorithms would make perfect choices among job applicants and would make selection panels a thing of the past: "Talent management startup Clustree uses big data to help human-resource departments find the right internal candidate for job vacancies. It does this by analysing millions of CVs to discern career paths and improve job recommendations. In October 2015, the startup, launched in 2013 by Bénédicte de Raphélis Soissan, raised \$2.9 million from Alven Capital" (Medeiros 2016). 
All of these examples share the same logic: It is claimed that collecting and analysing more data results in the better prevention of and the capacity to overcome problems society faces. As a result, big data would make humans healthier, wealthier and more educated and society safer, cleaner and more democratic. To increase the quantity of the computational analysis of society and the data it generates would give rise to better qualities.

Big data logic disregards that society's problems are grounded in power structures. Physical and mental health have to do with environmental influences such as pollution, radiation, human stress, working conditions, human happiness, the amount of available free time, the education system, etc. Productivity depends on human capacities and the development of human skills. Air pollution is predominantly the outcome of fossil fuel-based capitalism. Social unrest, crime and terrorism are grounded in social inequalities and the asymmetric distribution of power. Finding the best candidate for a job is not simply a matter of formal qualification, but also of informal, communicative and social skills. Big data's logic of digital positivism only stresses potential positive impacts datafication could have. It disregards potential negative impacts.

In the time of neoliberal health care, where public investments are scarce, big data can be used for identifying who should be treated (e.g. who are wealthy enough) and who should go without treatment. Big data in urban and political settings can be used for trying to predict who may become a criminal or a terrorist. But such predictive algorithms can result in false positives, undermine democracy and contribute to the creation of a fascist police state. Collecting big data about applicants and employees can foster economic surveillance that violates privacy and installs totalitarian management controls. Datafication requires server farms and ever more digital devices, which increases energy consumption. Energy sources are today predominantly based on fossil fuels or nuclear energy and only to a smaller degree on renewable and clean energy sources (Fuchs 2017b). Increasing big data can therefore have negative rebound effects on the environment.

The big data fetishism of Wired and The Economist is a good example of digital fetishism. The authors, entrepreneurs, consultants and stories featured in such magazines express constant astonishment about what computers can do. "My god it's incredible what it - the machine - can do!"'12 (Anders 2016, 34 [G: Anders 1956, 28]). Big data fetishism disregards the societal context, contradictions and power structures, into which computer technologies are embedded. It argues for the replacement of human decisions and actions by algorithmic logic.

In the age of big data and the Internet of things, human activity continues to be automated. Automation is not just limited to the economy, but extends into all realms of everyday life. Drone-bombs, self-driving cars and trains, Twitter bots, automated phone calls with computer-generated voices, algorithmic auctions and trading, the automated regulation of water, energy and heating in smart homes, and smart retail and shopping are only some of the examples. A study estimates that in the third 2016-US presidential election debate, political bots accounted for $36.1 \%$ of the proTrump tweets (Kollanyi, Howard and Woolley 2016). Politics has become semiautomated. It has become difficult to discern what has been written, posted, liked, and re-posted by a human being or machine. Algorithms today strongly influence politics. The problem is that machines cannot make political judgements. They do not

\footnotetext{
${ }^{12}$ In the German original: „,Mein Gott, was die kann!' (nämlich die Maschine)“.
} 
have morals or the ability to reflect. They cannot make judgements that are based on morals or politics. Fake attention and fake news can to a certain degree influence and thereby manipulate political decisions. Automated politics undermines democracy.

Anders $(1962 / 2014,193)$ argued that in the age of the antiquation of the human being, reification takes on a form where products and technologies "transform themselves into pseudo-persons". This insight has obtained an important truth today, where it is problematic that, in semi-automated politics and action in the age of big data, it can be difficult to discern whether humans or machines create information, visibility and attention. Secret algorithms determine your Facebook newsfeed and Google results. Social media bots are algorithms that try to intervene into these algorithms and to create artificial attention. Attention and visibility thereby not just become semi-automatic, but also communication power-asymmetries can be enforced. Post-truth politics on social media does not democratise politics. It does not shift away power from experts towards citizens, but rather enforces giving attention power to an elite.

\subsection{Post-Humanist Ideology}

Humans' Promethean shame and desire to become identical with machines is most evident in post-humanist ideology. Originating in structuralism's announcement of the death of the human subject, post-humanism aims at overcoming human existence and turning humans into machines. The computer scientist Ray Kurzweil argues that the miniaturization of computers will result in nanobots that can enter and repair the human body. Human life could thereby be prolonged to the stage where it would become possible to download the human brain onto computers, making humans immortal:

"The power (price-performance, speed, capacity, and bandwidth) of information technologies is growing exponentially at an even faster pace, now doubling about every year. [...] Human brain scanning is one of these exponentially improving technologies. [...] Nonbiological intelligence will be able to download skills and knowledge from other machines, eventually also from humans. [...] We will be able to reengineer all of the organs and systems in our biological bodies and brains to be vastly more capable. [...] Nanobots will have myriad roles within the human body, including reversing human aging (to the extent that this task will not already have been completed through biotechnology, such as genetic engineering)" (Kurzweil 2005, 25, 26, 27, 28).

Kurzweil sees the computer as God, an omnipotent force that can radically transform nature. In Kurzweil's ideology, the human being's inferiority complex and admiration of the computer is taken to an extreme level so that the extinction of the human species is planned in order for humans to become parts of machines. Posthumanism is the ideological dream of the human "to become equal to his deities, the 
machines" ${ }^{13}$ (Anders 2016, 40 [G: 1956, 36]). Kurzweil and other post-humanists solve the mind-body problem in a dualistic manner by assuming that the human mind can exist independently from the body in a computer. But in reality, there is a dialectic of the mind and the body. When one of the two dies, the other dies too. If becoming immortal by becoming a cyborg were technically possible, then in a capitalist society it would be likely that this capacity would be used for perfecting and immortalising the ruling class and fostering the annihilation of all those who do not fit into the capitalist models of productivity and entrepreneurship and of those who are ideologically scapegoated as harming capitalist growth. To "leave the human condition behind and stop being human" implies "the climax of all possible dehumanisation"14 (Anders 2016, 44 [G: 1956, 41-42]). Given that capitalism always has fascist potentials and we live in times of crises that can produce fascism, fostering post-humanism can also easily foster fascism. The combination of cyborgism and capitalism is likely to result in cyber-fascism, post-human fascism.

\section{Günther Anders' Analysis of Television and Radio}

The second part of the first volume of Die Antiquiertheit des Menschen is dedicated to the analysis of broadcasting (Anders 1956, 97-211). It holds the title Die Welt als Phantom und Matrize (The World as Phantom and Matrix). Anders criticises that commercial broadcasting addresses the audience as consumers of commodities in order to increase sales. "The world has now become an 'exposition'; and certainly an advertising exposition that is impossible not to visit, because we always already find ourselves in the middle of it"15 (Anders 1980a, 161).

Anders focuses on three aspects in his critique of commercial broadcasting: labour, ideology, and alternatives.

\subsection{Audience and Consumer Labour}

As the first aspect of his critique, Anders stresses the role of labour in commercial media. He argues that consuming commercial broadcasts is a form of labour: "Everyone is in a way employed and occupied as a homeworker. [...] The process becomes completely paradoxical insofar as the homeworker has to pay for his labour instead of being paid for his cooperation; he namely has to pay for the means of production (the device and, in many countries, even for the broadcasts) [...] So he pays for selling himself" ${ }^{\prime 16}$ (Anders 1956, 103). Consumption of a TV commercial programme is "camouflaged labour"17 (Anders 1980b).

The first volume of Anders' principal work Die Antiquiertheit des Menschen was published in 1956. Around the same time, the Canadian Marxist Dallas Smythe

\footnotetext{
${ }^{13}$ In German original: „Sein Traum wäre es natürlich, seinen Göttern: den Apparaten, gleich zu werden, richtiger: innen ganz und gar, gewissermaßen ko-substanziell zuzugehören“.

${ }^{14}$ In German original: ,,,das Mensch-Sein hinter sich bringen'. [...] ist [...] der Klimax möglicher Dehumanisierung“.

${ }^{15}$ Translation from German: „Die Welt ist nun zur ,Ausstellung' geworden, und zwar zu einer Werbeausstellung, die nicht zu besuchen unmöglich ist, weil wir uns immer schon ohnehin in ihr befinden".

${ }^{16}$ Translation from German: „Jedermann ist gewissermaßen als Heimarbeiter angestellt und beschäftigt. [...] Vollends paradox wird der Vorgang dadurch, daß der Heimarbeiter, statt für diese seine Mitarbeit entlohnt zu werden, selbst für sie zu zahlen hat; nämlich für die Produktionsmittel (das Gerät und, jedenfalls in vielen Ländern, auch für die Sendungen) [...] Er zahlt also dafür, daß er sich selbst verkauft".

17 "getarnte Arbeit" (Anders 1980a, 182).
} 
formulated foundations of a critique of the political economy of commercial media that has striking parallels with Anders' approach (see Smythe 1951, for a detailed discussion see Fuchs 2012). Smythe later developed this approach into the theory of the audience commodity and audience labour. He argues that the content of advertising-funded media is not a commodity, but a "free lunch" (Smythe 1977, 5). The audience's attention would be the commodity of advertising-funded media. Audiences would by watching commercial television, listening to commercial radio, or reading commercial publications, produce an audience commodity that is sold by corporate media to advertising clients. Smythe therefore speaks of audience labour as a productive form of labour that produces the audience commodity. Audiences "work to market [...] things to them- selves" (Smythe 1981, 4). "Because audience power is produced, sold, purchased and consumed, it commands a price and is a commodity. [...] Your audience members contribute your unpaid work time and in exchange you receive the program material and the explicit advertisements" (Smythe 1981, 26, 233).

Smythe and Anders share the insight that in advertising-based consumer capitalism, consumers become productive workers whose selves are sold. Anders in this context uses the notion of the homeworker, Smythe the concept of audience labour. It is unlikely that the Austrian philosopher and the Canadian political economist were aware of each other's works when they were developing these ideas in the early 1950s. They independently developed a critical theory update of the concept of labour for the age of consumer capitalism.

In big data capitalism, the homeworker, audience labour and the audience commodity have been transformed (Fuchs 2017a). Social media are based on usergenerated content, data and metadata. To a certain degree, Internet users behave like classical audiences who consume, watch, listen and read. But to a particular extent they are also producers of content, data and social relations. All audiences produce meanings in consumption. But in producing such meanings, users of commercial social media also produce data and metadata that make their interests, relations and behaviour traceable. Big data emerged from the surveillance interests of online corporations and state agencies that want to control users' behaviours in order to accumulate profits and intelligence. Via big-data-based surveillance, online ads are being targeted and personalised. Predictive algorithms are used for trying to predict online behaviour. The price of the big data commodity is set in algorithmic auctions. By turning into the big data commodity and digital labour, the audience commodity and audience labour have become data- and surveillance-based, targeted, and algorithmic. Anders' homeworker has today become a digital homeworker and Smythe's audience worker a user-worker.

Anders (1980a, 210-246) argues that one of the consequences of the capitalist world machine is that privacy becomes antiquated. The result of the application of surveillance technologies is according to Anders that "[n]ot only is it true that 'The world is delivered to your home', but also: 'Your home is delivered to the world"'18 (Anders 1980b). Surveillance means "the delivery of man to the world"19 (Ibid.). "As

\footnotetext{
18 „Nicht nur gilt: ,Die Welt wird ins Haus geliefert' sondern auch: ,Das Haus wird der Welt ausgeliefert" (Anders 1980a, 210).

${ }^{19}$ „Auslieferung des Menschen an die Welt" (Anders 1980a, 210).
} 
surveillance devices are used routinely, the main premise of totalitarianism is already created and, with it, totalitarianism itself ${ }^{\prime 20}$ (Ibid.).

In the age of the Internet and surveillance capitalism, the world is constantly and in real time delivered to us. We - and our activities, our interests, our communication, our contacts - are constantly delivered not to the world, but to our contacts and at the same time to online corporations and state security authorities. Edward Snowden's revelations have shown that big data capitalism is driven by data corporations' interest in amassing data about as many of our online activities as possible and state authorities' interest in monitoring data flows because they pretend to assume or seem to assume that they can thereby prevent terrorism. The problem of this approach is that it creates a huge political-economic surveillance machine in which humans are reduced to the status of consumers and are at the same time treated as if all of them are terrorists. Categorical exploitation and categorical suspicion fuse, the combination of big data capital and the big data state creates a totalitarian surveillance machine that undermines privacy and civil rights.

\subsection{Ideology and the Media}

Ideology is the second aspect of Anders' critique of commercial media. In the tradition of Georg Lukács and the Frankfurt School, Anders understands ideology as the production of false consciousness. But he argues that false consciousness is just an immediate goal that ideologues want to achieve. They would also aim at creating false will and ultimately false action: Ideology's "immediate goal consists in producing 'false consciousness' ", but it is an "apparatus for the production of false action"21 (Anders 1980). "The truth of ideology (that is: true compliance with the interest that lies at the basis of its production) is false praxis" 22 (Anders 1980b).

Anders argues that the commercial broadcast is a phantom world that is half present and half absent (Anders 1956, 111). The flood of images by "showing the world, veils the world" ${ }^{\prime 2}$ (Anders 1956, 4). The difference between appearance and being would disappear (111), the event would be shaped by the "matrix of its reproduction"24 (111). "Reality is transformed into the reproduction of its images"25 (179).

Anders argues that broadcasting results in banalisation (Verbiederung) and that it neutralises politics and critique. The cause of these forces would not be technological but political-economic in nature: "The fundamental neutraliser is [...] the commodity character of all phenomena" 26 (121). Commercial media manufacture reality: "There are really numerous events that happen as they happen in order to be useable as

\footnotetext{
${ }^{20}$ „Wo Abhörapparate mit Selbstverständlichkeit verwendet werden, da ist die Hauptvoraussetzung des Totalitarismus geschaffen; und damit dieser selbst" (Anders 1980a, 221).

${ }^{21}$ „Mag auch ihr Nächstziel darin bestehen, ,falsches Bewußtsein' herzustellen“, so ist Ideologie „das Gerät zur Produktion falschen Handelns“ (Anders 1980a, 190).

22 „Die Wahrheit der Ideologie (das heißt: die wahre Erfüllung des ihrer Herstellung zugrundeliegenden Interesses) ist die falsche Praxis" (Anders 1980a, 191).

23 "die Welt zeigend, die Welt verhüllten".

24 Translation from German: „Matrize ihrer Reproduktion”.

${ }^{25}$ Translation from German: "daß das Wirkliche zum Abbild seiner Bilder wird“.

${ }^{26}$ Translation from German: „Der fundamentale Neutralisator [...] ist der Warencharakter aller Erscheinungen“.
} 
broadcasts" ${ }^{27}$ (191). According to Anders, the commodity requires banalisation in order to be bought and sold. "Since the broadcast is a commodity, it too must be served in status that is pleasant to our eyes and ears, optimally ready for consumption, alienated, removed from its core, and assimilated; that is, in a manner that it addresses us as our simile, custom-designed, as if it were part of $u s^{\prime \prime 28}$ (Anders 1956, 122). Anders' notion of banalisation has parallels to Herbert Macuse's (1964) notion of one-dimensional man. Marcuse analyses how the commercialisation of culture creates "one-dimensional thought and behavior in which ideas, aspirations, and objectives that, by their content, transcend the established universe of discourse and action are either repelled or reduced to terms of this universe" (Marcuse 1964, 14).

Unilateralism is another aspect of ideological media. "The relation human-world becomes unilateral" ${ }^{29}$ (Anders 1956, 129). By the unilateralism of communication, Anders means a one-sided information flow: "Since the devices speak on our behalf, they also deprive us of language; they deprive us of our capacity to speak, our opportunities to speak, and of our pleasure to speak"30 (Anders 1956, 107). "Without the radio the massive successes of Hitler would have been unthinkable. Fascism and radio went hand in hand ${ }^{\prime 31}$ (Anders 1980b).

The one-dimensional human is for Anders at the same time dualistic, a phantom. It is present and absent and lives at the same time in different realities (the real and the imagined world, reality and fiction, reality and simulation). It is occupied with many activities at the same time and can therefore not be focused. It is not an individual, but a di-vidual (Divisum). The divided individual is "divided into a multiplicity of functions"32 (Anders 1956, 141)

Anders argues that commercial media present the micro world as macro world and the macro world as micro world (Anders 1956, 152-153). There is both sensationalism and anti-sensationalism (153). The unimportant is presented as sensation and spectacle, whereas truly important and dangerous developments are minimised. Whereas sensationalism makes mountains out of molehills, antisensationalism makes molehills out of mountains (153).

So for Anders, commercial media's manufacturing of reality entails banalisation, unilateralism, di-vidualism, sensationalism, and anti-sensationalism. One can say that these are ideological strategies. But for Anders, capitalism is today "postideological" and ideology has become antiquated. It is not that ideologies no longer exist. Anders rather says they are no longer needed because false statements and lies about the world have become the world (Anders 1956, 193; see also Anders 1980a, 188-192). Ideology produces post-ideology. Anders (1980a, 261) argues that

\footnotetext{
${ }^{27}$ Translation from German: „Wirklich gibt es zahllose Geschehnisse, die nur deshalb so geschehen, wie sie geschehen, damit sie als Sendungen brauchbar seien“.

${ }^{28}$ Translation from German: „Da nun auch die Sendung eine Ware ist, muß auch sie in augen- und ohrengerechtem, in einem optimal genußbereiten, entfremdeten, entkernten, assimilierbaren Zustande serviert werden; also so, daß sie uns als unser Simile, nach unserem Maße Zugeschnittenes, als unsereins anspricht".

${ }^{29}$ Translation from German: „Die Beziehung Mensch-Welt wird unilateral“.

${ }^{30}$ Translation from German: „Da uns die Geräte das Sprechen abnehmen, nehmen sie uns auch die Sprache fort; berauben sie uns unserer Ausdrucksfähigkeit, unserer Sprachgelegenheit, ja unserer Sprachlust".

${ }^{31}$ In German original: „Ohne dieses [das Radio] sind die Massenerfolge Hitlers nicht denkbar. Faschismus und Rundfunk sind Korrelate" (Anders 1980a, 88).

${ }^{32}$ Translation from German: „in eine Mehrzahl von Funktionen zerlegt“.
} 
ideologies are theoretical systems that interpret the whole (although in a false manner): "The images coming from all over the world that are ceaselessly transmitted to us have nothing to do with what were still called, only fifty years ago, images of the world. Now they are always only single trees, not the forest" ${ }^{\prime 33}$ (Anders 1980b).

The ideological strategies of banalisation, unilateralism, di-vidualism, sensationalism, and anti-sensationalism remain relevant and have taken on new qualities in big data capitalism.

Contemporary networked digital media platforms operate at extremely high speed and publish an immense amount of content. In the world of big and ultra-accelerated content and data, attention is a scarce good. In order to attract attention online, content today tends to be compressed, short, superficial, and ephemeral. The feudalisation of the public sphere, the world of engagement, publishing and debate, has in the age of Twitter and reality TV taken on the form of highly accelerated banalisation and tabloidisation that appears to democratise the public sphere (usergenerated content as "participatory culture"), but is in essence the antiquation of engaging political information, political communication and political debate.

Also unilaterialism has taken on new forms in the world of social media and usergenerated content. The broadcast media's monopoly of voice has been broken. Now (almost) everyone can speak, broadcast, post, comment, etc. online. The computer is a universal machine, a tool for the production, dissemination and consumption of information. Technological convergence of what in traditional broadcasting are different technologies and institutions has enabled the emergence of prosumption (productive consumption, consumers who are producers of information). But the capitalist world of prosumption is far from democratic. It is driven by the logic of accumulating profits and attention. Online attention is time. Time is scarce. Time is money. Online attention turns into money. Given the capitalist stratification of the online world, we also find a stratification of attention: Celebrities, corporations and some others dominate online visibility. They together form the online elite that achieves high attention and visibility. In contrast, proletarian users can speak and post, but are hardly heard. The result is a class conflict between online celebs that accumulate and are rich in attention, and online proletarians that are the capitalist online attention economy's poor.

In the age of social media, the di-vidual has already become antiquated and has turned into a multi-vidual. We are constantly confronted with a vast amount of content, opinions, choices, new releases, updates, requests for inputs, messages, etc. The problem is that the multiverse of information is to a large degree one and the same type of superficial information that distracts attention from information and communication that really matters and can make a difference to the world. Critical, dialectical information often remains buried and unrecognised in the vast flow of big data. One-dimensionality disguises itself as plurality. Information that stands out from big data and achieves mass attention as sensation and spectacle is often banal and trivial. Meanwhile, critiques and thoughtful ideas that could make a real difference, that are based on complex arguments and require space and time for development, are mostly overlooked, ignored and repressed anti-sensations.

${ }^{33}$ In German original: „Die ,Bilder aus aller Welt', die man uns pausenlos zuleitet, haben mit dem, was man noch vor fünfzig Jahren ,Weltbilder' nannte, überhaupt nichts mehr zu tun. Immer sind es einzelne Bäume statt des Waldes" (Anders 1980a, 261-262). 
Although there is also classical censorship in the online world, the main form of repression online is equal to what Herbert Marcuse (1969) terms repressive tolerance:

\begin{abstract}
"All points of view can be heard: [...] in endlessly dragging debates over the media, the stupid opinion is treated with the same respect as the intelligent one, the misinformed may talk as long as the informed, and propaganda rides along with education, truth with falsehood. This pure toleration of sense and nonsense is justified by the democratic argument that [...] all contesting opinions must be submitted to 'the people' for its deliberation and choice. [...] Other words can be spoken and heard, other ideas can be expressed, but, at the massive scale of the conservative majority (outside such enclaves as the intelligentsia), they are immediately 'evaluated' (i.e. automatically understood) in terms of the public language-a language which determines 'a priori' the direction in which the thought process moves" (Marcuse 1969, 94, 96).
\end{abstract}

On social media, all opinions can be posted and all content can be assessed and commented on in real-time. But given the asymmetries of visibility and attention in the flood of information (due to e.g. sponsored/branded content, targeted advertising, reputational hierarchies, etc.), non-trivial, complex and critical voices have a harder time to be recognised and to make a difference.

In the age of social media and prosumption, we forget that we are working and when we are working. Anders' notion that there is a Promethean gap between doing and feeling has reached a new level, as we in real time can access lots of information about the world and communicate with many parts of the world, but at the same time labour no longer feels like, and hardly is perceived as, exploitation and a class relation.

In classical commodity fetishism, the "definite social relation between men themselves" assumes "the fantastic form of a relation between things" (Marx 1867, 165). In the world of capitalist social media, commodity fetishism has become antiquated and has turned into inverse commodity fetishism. When using Facebook or Google, we cannot see and experience the commodity, but rather experience sociality as if it were unmediated by the commodity form. We do not pay money for accessing social media because it provides access as a "free lunch". But in reality this lunch is not for free, but rather is a means for exploiting our digital labour so that personal data is turned into a commodity behind our backs, not visible to and not directly experienceable for us. In inverse commodity fetishism, the social hides the commodity form. Alienation appears as social and non-alienated fun and pleasure. Günther Anders anticipated this development: "Despite the fact that we really live in an alienated world, the world is presented to us as if it is a world for us, as if it were our own and like ourselves"34 $(1956,116)$.

\footnotetext{
${ }^{34}$ Translation from German: „Obwohl wir in Wahrheit in einer entfremdeten Welt leben, wird uns die Welt so dargeboten, als ob sie für uns da wäre, als ob sie unsere wäre und unseresgleichen".
} 
"As consumers we contemporaries are today consistently 'secret agents" 35 (Anders 1980a, 171) because it is kept secret "that, for what and for whom he performs his activity when he sits in front of his goggle-box" ${ }^{36}$ (Ibid. 170). The gogglebox has today turned into the Google-universe. In the case of the goggle-box that broadcasts advertising-funded programmes, audience labour is kept ideologically secret through the consumers' enjoyment and relaxation. In the Google universe of social media, inverse commodity fetishism creates the immediate experience of sociality so that communication and sociality act as the forces that keep the status of users as workers secret.

\subsection{Alternatives}

When reading Anders one must always bear in mind that he uses exaggeration as a means of criticism. What drove Anders' radical critique was a deep-seated humanism and concerns about the human being's situation in capitalist societies. He was not opposed to alternative forms and organisations of communication. He argues that the key task is the formation of moral phantasy that aims at overcoming the Promethean gap (Anders 1956, 273). Anders favoured means that allow humans to develop such phantasy.

In the preface to the $5^{\text {th }}$ edition of the first volume of Die Antiquiertheit des Menschen, Anders argues that the Vietnam war, where television and the media showed images of killed civilians, which would have had an enlightening effect:

"It has, in fact, been shown that, in certain situations, television images can deliver the reality, in which we would otherwise not participate in at all, into the home and can shake us up and motivate us to take historically important steps. Perceived images are worse than perceived reality, but they are better than nothing. The images of the Vietnam War that were channelled into American homes day by day, really 'opened' the screengazing eyes of millions of citizens eyes who were staring at the screen, triggering a protest that greatly contributed to the end of the genocide that took place at that time"37 (1956, VIII).

The question is how alternative media and digital media that strengthen human imagination could look like today. Certainly they have to be non-commercial and pursue a non-profit agenda.

\footnotetext{
${ }^{35}$ Translation from German: „Als Konsumenten sind wir Heutigen durchweg ,Geheimagenten'“.

${ }^{36}$ Translation from German: „weil vor ihm selbst geheimgehalten wird, daß er, wofür er und für wen er, wenn er vor seiner Schüssel sitzt, seine Tätigkeit ausübt".

${ }^{37}$ Translation from German: „Unterdessen hat es sich nämlich herausgestellt, daß Fernsehbilder doch in gewissen Situationen die Wirklichkeit, deren wir sonst überhaupt nicht teilhaftig würden, ins Haus liefern und uns erschüttern und zu geschichtlich wichtigen

Schritten motivieren können. Wahrgenommene Bilder sind zwar schlechter als wahrgenommene Realität, aber sie sind doch besser als nichts. Die täglich in die amerikanischen Heime kanalisierten Bilder vom vietnamesischen Kriegsschauplatz haben Millionen von Bürgern die auf die Mattscheibe starrenden Augen erst wirklich ,geöffnet' und einen Protest ausgelöst, der sehr erheblich beigetragen hat zum Abbruch des damaligen Genozids“ (Anders 1956, VIII).
} 
Club 2 in Austria and After Dark in Britain were prototypes of slow broadcast media. The Club 2 debate format originated in the 1970s in the context of the Austrian Broadcasting Corporation (ORF), Austria's public service broadcaster. Club 2 was an open-ended, live, uncensored, controversial debate with diverse participants. Club 2 was a true public sphere.

We need slow media. Offline and online. Slow media. And slow media 2.0. Is a new version of Club 2 possible today? What could Club 2.0 look like? Speaking of a second version can on the one hand mean that the Club 2 concept could be revived to help strengthening the public sphere in times of authoritarian capitalism. On the other hand, one has to take into account that society does not stand still. Rather, it develops dynamically and has created new realities such as the Internet that has become a key part of public communication. Club 2.0 therefore also means a somewhat updated concept of Club 2 that sticks to its ground rules but also extends the concept. If Club 2.0 can go from possibility to reality is not simply a technical question. It is a question of political economy. It is a political question because it requires the decision to break with the logic of commercial, entertainment-oriented TV dominated by reality TV and comparable formats. Club 2.0 requires a political choice in favour of public service media and public interest media. Club 2.0 is also an economic question because realising it requires breaking with the principles that shape the media today, such as high speed, superficiality, brevity, the algorithmisation and automation of human communication, post-truth, the spectacle, etc. Club 2.0 is a question of resources and changing the media system's power relations.

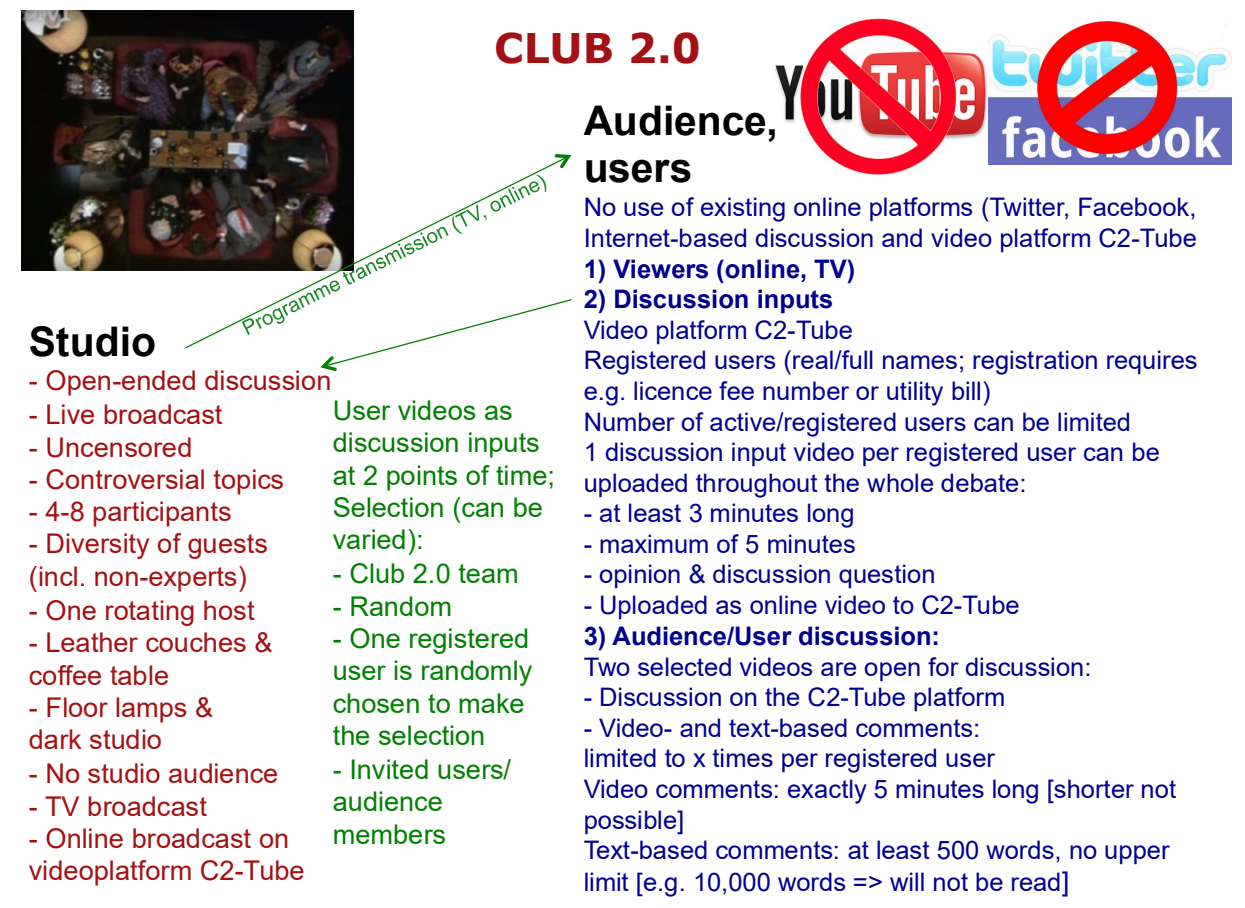

Figure 1: Concept of Club 2.0

Figure 1 visualises a possible concept of Club 2.0. This model is a basic idea that certainly can be varied in many ways and is merely one of many possible versions. The key aspects are the following: 
- Club 2/After Dark's ground rules: Club 2.0 uses and extends the traditional principles of Club 2/After Dark. The live television part requires all of the traditional principles of Club 2/After Dark. These ground rules are key for the format's success. Club 2.0's broadcasts need to be open-ended, live, and uncensored.

- Cross-medium: Club 2.0 is a cross-medium that brings together live television and the Internet.

- Online video: Club 2.0 live broadcasts are available online via a video platform.

- Autonomous social media, no traditional social media: Existing commercial social media platforms (YouTube, Twitter, Facebook, etc.) are not suited because they are not based on the principles of slow media and public interest. Broadcasting Club 2.0 over YouTube would for example result in frequent advertising breaks that would disrupt and disable discussion.

- Autonomous video platform C2Tube: Club 2.0 requires its own video platform that we can provisionally call C2Tube. C2Tube poses the possibility for viewers to watch the debate online and via a diversity of technical devices.

- Interactivity: C2Tube also allows interactive features that can be used to a certain degree.

- User-generated discussion inputs: There is the possibility for discussion inputs generated by users. Such a feature requires that users are non-anonymous and register on the platform. Anonymity encourages Godwin's law that says that "as an anonymous online discussion grows longer, the probability of a comparison involving Hitler approaches 1". Setting an upper limit of registrations or activating only a certain number of users during a specific debate allows limiting the number of registered and active users. The selection of active users can for example be made randomly. Or all users can be allowed to participate. User-generated discussion inputs should ideally be in video format. The number of user-generated discussion inputs that can be generated should best be limited (ideally to just one per active user). User-generated discussion inputs can be uploaded to the $\mathrm{C} 2$ platform.

- Interfacing the studio debate with user-generated videos: At certain points of time during the live broadcast, a user-generated video input is chosen and broadcast and informs the studio debate. Users in such videos formulate their own views and can also provide a question for discussion. Ideally during a two to three hour-long debate, about two user-generated videos could be broadcast. Inevitably a selection mechanism is needed for deciding which user-generated videos are broadcast. There are several principles such as random selection, selection by the Club 2.0 production team, random choice of a registered user who is enabled to choose the video, special guests who make the selection, etc.

- User discussion: Club 2.0 also enables discussion between users. Discussion could take place simultaneously to the live broadcast and/or after it. The two selected user-generated $\mathrm{C} 2$ videos can be opened up for discussion on the $\mathrm{C} 2$ platform. Ideally, video- and text-based comments should be possible. There should be a minimum length for text-based comments and maybe a maximum length for video comments. In order to stick with the principle of slow media and avoid the Twitter effect of accelerated standstill, the number of video and text comments a single user can post per debate should be limited.

- Forgetting data: Videos are fairly large and storage-intensive. Therefore the question is what should happen to all those videos that are uploaded, but not broadcast and not opened for discussion. Given that they have no practical use, 
they could be deleted. This means that the users must be aware of the fact that uploading a video means loss of data. Contemporary social media store all data and meta-data forever. Forgetting data can therefore be used as a counterprinciple. The online debates that feature text and video comments could either be preserved or deleted after a certain period of time.

- Privacy-friendliness: Contemporary social media use data and user surveillance for economic and political purposes, i.e. for making monetary profits by selling targeted advertisements and implementing a political surveillance society that promises more security but undermines privacy and installs a regime of categorical suspicion. Club 2.0's way of dealing with data should be privacy friendly, only store the minimum amount of data necessary for operating the platform, not sell user data, and in general use good practices of data and privacy protection. This principle is also called privacy-by-design, which means that privacy is designed into the platform and the format. This does however not mean that users who debate publicly are anonymous. Privacy rather relates to the way user data is stored and handled.

- Social production: Contemporary social media are highly individualistic. The production of user-generated Club 2.0 input videos could in contrast take on the form of social production that transcends individualism and creates truly social media content by integrating Club 2.0 into educational institutions (schools, universities, adult education, etc.) where individuals together learn by co-creating video content as input for discussions. For doing so, the topic of a specific Club 2.0 evening needs to be known in advance, which can be achieved by publishing a description. Groups of individuals can get together and prepare videos that they can on the evening of the broadcast upload to C2Tube once the uploading possibility is enabled.

Club 2.0 alone would not achieve a better world. In times of authoritarian, high-speed capitalism, complexity and critique are largely missing from the news and political information and communication. Club 2.0 could contribute to strengthening the public sphere. Public sphere communication is part of society's critical capacities. With the rise of authoritarian capitalism, we have witnessed intensifying attacks on critical capacities. Imagine Donald Trump sitting on the Club 2.0 leather couch together with some of his hardest critics: In this situation, there is no Twitter that allows him to reduce interaction to throwing short sound bites into the anonymous virtual space from a distance. There is only face-to-face live discussion without escape, where claims and counter-claims are explored, ideologies are questioned, opposite opinions are given time to meet and clash, etc. Club 2.0 would bring back a bit of dialectics into a one-dimensional world, in which the public sphere is under attack by authoritarian capitalism.

\section{Klaus Eichmann and Claude Eatherly: Guinther Anders' Engagement with the Son of the Shoah-Organiser and the Hiroshima-Nuclear Bomb Pilot}

For Anders, the $20^{\text {th }}$ century was an age of catastrophe epitomised by Auschwitz and the atom bomb. The apocalyptic potentials of technologies and society has become so large that the Promethean gap creates apocalyptic blindness (1956, 233-308). Blind belief in progress is one of the sources of apocalyptic blindness (276-277). New nihilistic forces have been unleashed that have created the potential for the reduction to nothingness, the "reduction ad nihil" (239). In the age of catastrophes, nihilism and annihilation have merged into what Anders terms annihilism (Annihilismus) (304). 


\subsection{Guinther Anders and Klaus Eichmann}

Adolf Eichmann (1906-1962) was a senior assault unit leader in the SS, who in the Reich Main Security Office was in charge of the organisation of the displacement and deportation of Jews. After the end of the Second World War, Eichmann as one of the main people responsible for the Shoah escaped from capital punishment in the Nuremberg Trials by first going underground and then fleeing to Argentina. The Mossad transferred Eichmann in 1960 to Israel, where he was put on trial in 1961 and found guilty of crimes against the Jewish people, war crimes, crimes against humanity, the extermination of minorities, and membership in criminal organisations (the SS, the Gestapo, and the SS's intelligence service). Eichmann was sentenced to death and hanged. Klaus Eichmann is Adolf Eichmann's oldest child. In 1964, Günther Anders (1964a, 1964b) sent a long letter to Klaus Eichmann that was published as a book.

In this letter, Anders characterises the Nazi regime and the Shoah as a monstrous machine and coins the concept of Eichmanns. Eichmanns are the "administrators and performers" ${ }^{38}$ (Anders 1964b) of monstrosities. Eichmanns are servile (carrying out monstrosities like any other job), disgraceful (aspiring to their positions), stubborn (willing to lose their humanity for gaining total power), greedy, and cowardly (Anders 1964a, 19). Anders' characterisation of Eichmanns reminds us of Erich Fromm's analysis of the fascist as authoritarian personality: "The love for the powerful and the hatred for the powerless which is so typical of the sado-masochistic character explains a great deal of Hitler's and his followers' political actions" (Fromm 1942/2001, 200). The Eichmanns' servility, disgracefulness, stubbornness, greed and cowardice are simultaneous expressions of striving for and submitting to power and executing violence against the powerless. Adolf Eichmann strove for power and in order to be powerful submitted to the Nazi machine's logic. As one of its powerful agents, he executed the regimes terror against its victims.

Eichmann is for Anders a symbol of the monstrosities that are an immanent potential of modern society and modern technologies. Anders in his letter explicitly refers to the Promethean gap without calling this phenomenon by this name (Anders 1964a, 24). The effect of the monstrosity of technology is that "the 'outsized' leaves us cold - or rather, not even cold (since coldness would also be a kind of feeling), but completely indifferent; we are becoming 'emotional illiterates'" ${ }^{39}$ (Anders 1964b). Adolf Eichmann's trial showed that he considered the killing of six million Jews with emotional coldness as a bureaucratic act and act of obedience. He considered himself innocent and argued that he was just a cog in the machine.

Hannah Arendt (1977) argues that Adolf Eichmann was not an extraordinarily "diabolical or demonic" person (288), but one of many ordinary, banal Germans. He was "terribly and terrifyingly normal" (276) in his worship of power as fetish. Monstrosity requires what Arendt terms the banality of evil at the level of the individuals and groups carrying it out. But in considering monstrosity and evil as banal, there is a certain danger of excusing the perpetrators, which became evident in Adolf Eichmann's trial. In his final plea, Eichmann argued that he was not guilty because he only obeyed orders:

${ }^{38}$ In German original: „Leiter und Handlanger“ (Anders 1964a, 19).

${ }^{39}$ In German original: „das ,zu Große' läßt uns kalt, nein (denn auch Kälte wäre ja noch eine Art von Gefühl) noch nicht einmal kalt, sondern völlig unangerührt: wir werden zu ,emotionalen Analphabeten'“ (Anders 1964a, 28). 
"The guilt for the mass murder is solely that of the political leaders. [...] I accuse the leaders of abusing my obedience. [...] Obedience is commended as a virtue. May I therefore ask that consideration be given to the fact that I obeyed, and not whom I obeyed. [...] I have already said that the top echelons, to which I did not belong, gave the orders, and they rightly, in my opinion, deserved punishment for the atrocities which were perpetrated on the victims on their orders. But the subordinates are now also victims. I am one of such victims" ${ }^{\prime 0}$. In his final plea to be pardoned, Eichmann wrote that there "is a need to draw a line between the leaders responsible and the people like me forced to serve as mere instruments in the hands of the leaders" (Kershner 2016).

Eichmann presented himself as a cog in the Nazi-machine. The machine would have to be blamed, not its cogs. Given that Adolf Eichmann was an ordinary and banal character operating as part of a terroristic machine, Anders raises an important question for the ethics of technology: Given the uncontrollability and monstrosity of technical apparatuses, can humans be blamed for the machines' negative effects? Anders' answer is that those who are creating monstrous machines do so as a conscious act they could refuse. They are therefore morally guilty. Adolf Eichmann's "guilt in regard to the monstrosity remains monstrous. Why? Because he can't be considered just another one of the millions of workers trapped in their specialization, who as part of the processes of the apparatus to which they were bound really had been completely stripped of the ability to conceptualize its ultimate and monstrous effects" ${ }^{\prime 11}$ (Anders 1964b).

Anders argues that the whole world has turned into a machine, the world machine (Anders 1964a, 52). Accumulation, expansion, colonialism, imperialism and maximum performance would be the very principles of the machine (Anders 1964a, 50-51). The "machines' thirst for accumulation is insatiable"42 (Anders 1964b). "The machines are being transformed into a single machine ${ }^{43}$, the "total machine" 44 (Anders 1980b).

Without explicitly acknowledging it, Anders takes up the Marxist-humanist argument that capitalism's logic of accumulation results in dehumanising and alienating effects. Global capitalism is the world machine that Anders talks about. The world machine's effect is that society and humans lose their humanity (Anders 1964a, 55). Anders' deep humanism becomes evident when he analyses how dehumanisation works. Out of Anders' examination of the deepest inhumanity speaks

\footnotetext{
40 The Trial of Adolf Eichmann, Session 120, http://www.nizkor.org/hweb/people/e/eichmannadolf/transcripts/Sessions/Session-120-03.html (accessed on May 3, 2017).

${ }^{41}$ In German original: „Seine Schuld am Monströsen bleibt trotzdem monströs. Warum? Deshalb, weil er jenen Millionen von Arbeitern, die zu ihren Spezialhandriffen verurteilt bleiben, und die durch die Indirektheit des Apparatsprozesses, dem sie integriert sind, der Möglichkeit, sich dessen letzte und ungeheure Effekte vorzustellen, tatsächlich beraubt sind, nicht zugezählt werden kann" (Anders 1964a, 31).

42 In German original: Der „Akkumulationshunger der Maschinen ist unstillbar" (Anders 1964a, 51).

${ }^{43}$ In German original: „Die Maschinen werden zu einer einzigen Maschine“ (Anders 1980a, 120).

${ }^{44}$ In German original: „Totalmaschine“ (Anders 1980a, 121).
} 
the political demand for a humane world, a world that accords to human essence, desires, needs and potentials.

Anders' letter ends in the suggestion that Klaus Eichmann shows solidarity with the anti-nuclear movement as a symbol for the protest against the possibilities of annihilation. Anders' letter remained unanswered, which led him at the age of 85 in 1988 to write a second letter to Klaus Eichmann (Anders 1964a, 76-97).

\subsection{Günther Anders and Claude Eatherly}

Claude Eatherly (1918-1978) was an officer in the US Army Air Forces. On August 6, 1945 , he was the pilot of an aircraft that supported dropping the nuclear bomb "Little Boy" on Hiroshima. Eatherly commanded the Straight Flush plane that explored the weather over Hiroshima and gave the "'go ahead' to the bomb-carrying plane to bomb the primary target" (Eatherly and Anders 1962, 81). Different from others involved in the bombing, who let themselves be celebrated as heroes, Eatherly was plagued by guilt. He unsuccessfully tried to commit suicide. Eatherly and Anders (1962) engaged in an exchange of letters about Hiroshima that lasted from 1959 until 1962. Eatherly was declared mentally ill and imprisoned in a mental hospital. The exchange between him and Anders provides indications that this was done to him because he spoke out publicly against nuclear warfare.

In his first letter to Eatherly, Anders argues that the atom bomb is characteristic of the age of the Promethean gap: "we can produce more than we can mentally reproduce; [...] we are not made for the effects which we can make by means of our man-made machines" (Eatherly and Anders 1962, 3). Paul Tibbits, pilot of the Enola Gay, the plane that dropped the atom bomb on Hiroshima, recalled: "I just hadn't even come close to imagine what the effect was. [...] One man is gonna go out with an airplane and a crew and a weapon and do what thousand airplanes used to do" 45 . Tibbits' description precisely confirms that nuclear warfare is one of the realms in which the Promethean gap operates.

Anders argues that Eatherly's doubts and criticisms of nuclear warfare show that although the pilot had been "misused as a screw" in the military machine, he "contrary to others [...] remained a human being", or became "one anew" (5). Eatherly says in one of the letters that war "is wild and inhuman. War should not be done by us, the head of all creatures. It seems that those sleeping under the ashes of Hiroshima were crying for peace" (31). Eatherly expressed the need for "the banishment of all nuclear weapons" (81).

When Eatherly was offered turning his life story into a Hollywood movie, Anders warned him that Hollywood's focus on profit and entertainment could portray him as "a harmless figure who does not belong to reality but only to the world of make believe" (28). Anders here draws on his theoretical analysis of broadcasting's transformation of the world into a phantom-world. He recommended to Eatherly to first write an autobiography and to legally demand that a movie would have to closely follow the book.

For Anders, Eichmann and Eatherly are two characteristic and symbolic figures of the age of the world machine. But the difference is that Eichmann never accepted any responsibility, whereas Eatherly changed his own political position and started opposing the military machine that he had himself been part of: "No, Eatherly is

\footnotetext{
${ }^{45}$ Paul Tibbets on Dropping the Atomic Bomb, http://www.history.com/topics/world-warii/bombing-of-hiroshima-and-nagasaki/videos/paul-tibbets-on-dropping-the-atomic-bomb
} (accessed on May 3, 2017). 
precisely not the twin of Eichmann, but his great and hope-inspiring antipode. Not the man who passes off machinery as a pretext for renouncing conscience, but, on the contrary the man who recognizes machinery as the fatal danger to conscience" (Eatherly and Anders 1962, 108-109).

"[I]f we don't accept the Eichmann arguments, we are considered - even in those countries which to-day are actually revolted by the special case Eichmann, as being disloyal or being traitors" (Eatherly and Anders 1962, 126). Authorities stigmatized Eatherly as being psychologically abnormal because he questioned imperialism's abnormal normality. Militarist ideology that is part of the dominant ideological narrative declares demands for peace as abnormal, war as peace, pacifism as violence, etc.

Herbert Marcuse has stressed that by ideologically and linguistically declaring violence to be normal, political horror is legitimated and rationalized: "Technological progress is accompanied by a progressive rationalization and even realization of the imaginary. The archetypes of horror as well as of joy, of war as well as of peace lose their catastrophic character. Their appearance in the daily life of the individuals is no longer that of irrational forces - their modern avatars are elements of technological domination, and subject to it" $(1964,253)$. Like Marcuse, Anders criticises the onedimensional, instrumental language used by the powerful to downplay the horrors of mass annihilation. He for example writes that the use of the term "megacorpse" for one hundred million dead human beings in military jargon indicates that "the inhibition against weapons of mass destruction has also been killed" ${ }^{46}$ (Anders 1982, 368). Anders argues that the ideological inversions of language and facts "vilifies us as 'troublemakers' because we cause trouble to their troublemaking"47 (Anders 1982, 370).

The Enola Gay pilot Tibbits also used this one-dimensional militaristic ideology that sees absolute violence as peace and that considers pacifists to be crazy. He argued that dropping the atom bombs on Hiroshima and Nagasaki "brought peace to the world at that time. [...] The morality of dropping that bomb was not my business. [...] Morality - there is no such thing in warfare. I don't care what we are dropping, an atom bomb, or whether you are dropping a 100 pound bomb, or you are shooting a riffle. You gotta leave the moral issue out of it" ${ }^{48}$. By arguing that war has no morality and that nuclear war is peace, Tibbits rationalises and defends his own role as the person who commanded the plane that dropped the nuclear bomb on Hiroshima. At the same time, he ideologically declares Eatherly crazy in order to assure himself of his own "normality" and the "normality" of the military potential to create a nuclear apocalypse. He says that he "never lost a night's sleep on the deal" and that Eatherly became "unbalanced after the end of the war, but he had had a problem of mental, should we say, incapacities/disabilities leading up to the war time"

\subsection{Annihilism Today}

Comparable to Horkheimer and Adorno's (2002) concept of the dialectic of Enlightenment, Anders stresses that capitalism turns against the Enlightenment

\footnotetext{
${ }^{46}$ Translation from German: „dann haben sie nämlich ihre Hemmungen gegenüber den Vernichtungswaffen ebenfalls vernichtet“.

${ }^{47}$ Translation from German: „die uns deshalb als ,Störenfriede' verleumden, weil wir ihre Friedensstörung stören".

${ }^{48}$ General Paul Tibbits: Reflections on Hiroshima, https://www.youtube.com/watch?v=nuYBxpKIMwg (accessed on May 4, 2017). ${ }^{49}$ Ibid.
} 
ideals and produces catastrophic potentials. Capitalism creates destructive potentials for the "self-destruction of enlightenment" (Horkheimer and Adorno 2002, xvi). By turning into a destructive machine, Enlightenment "mutilates people" (Ibid., 29) although it sets out to advance liberation and democracy. Konrad Paul Liessmann $(2002,50)$ formulates how Anders conceived of the negative dialectic: "It is precisely the triumphs of human beings that distance them from themselves, transcend the human measure and create the tendency that the human being disappears" 50 .

Similar to Horkheimer and Adorno, Anders argued that the Enlightenment's individualism and freedom backfired and turned the human being "into a screw in a machine of expansion that has been constructed by a minority" ${ }^{\prime \prime 1}$ (Anders 2001, 277). In Nazism, this screw "was allowed to carry the brand name of the 'master race'"'52 (Anders 2001, 277). For Anders, Auschwitz and Hiroshima were the consequences of carrying capitalism to the last instance. Anders adds to Horkheimer and Adorno's analysis that the destructive potentials of technology are so big that capitalism's last instance can turn into humanity's final instance.

The number of nuclear weapons has overall decreased in the past decades. At the time of the Cuban missile crisis in 1962, the number was 29,150 (Norris and Kristensen 2010). At 69,368, the amount of nuclear weapons reached a historical high in 1986 (Norris and Kristensen 2010). In 2016, there were 15,395 nuclear weapons, controlled by nine countries (USA, Russia, UK, France, China, India, Pakistan, Israel, North Korea) (SIPRI 2016). But the nuclear arsenals are continuously updated, modernised and supported by re-investments, maintaining that the nuclear threat of human extinction will remain a reality for a long time.

We are today seeing the development of a new dialectic of the Enlightenment that is spearheaded by figures such as Donald Trump, Nigel Farage, and Marine Le Pen. Neoliberalism advanced a narrow form of freedom focused on the freedom of the market and the freedom of private ownership. As a result, inequalities have risen and welfare states, and with them basic social protections, have been dismantled. Political agendas, including the social democratic agenda, have ignored the interest of the dominated class and declared class non-existent and a thing of the past. Neoliberal ideologues' common argument is that the rise of a new middle class has eliminated traditional class society. But today we witness the return of the repressed class in negative forms. Neoliberalism's contradiction between social freedom and market freedom backfired and created new authoritarian potentials, new nationalisms, and a heavily polarised political climate. Given that also some old authoritarians (e.g. in North Korea) control nuclear and other weapons of mass destruction, the clash of old and new authoritarianism increases the risk of humanity's annihilation. Günther Anders' warning that capitalism has catastrophic potentials remains highly topical today. As long as capitalism exists, we cannot rule out a crisis that produces fascism and new forms of annihilism.

\footnotetext{
50 Translation from German: „Es sind gerade die Triumphe des Menschen, die ihn von sich selbst entfernen, das menschliche Maß überschreiten und den Menschen tendenziell verschwinden lassen“.

${ }^{51}$ Translation from German: „zur Schraube innerhalb einer, von einer Minorität konstruierten, Expansionsmaschine“.

52 Translation from German: „zu einer Schraube, die die Firmenmarke Herrenmensch tragen durfte“.
} 


\subsection{Heidegger}

In the years 1921-1924, Günther Anders studied philosophy at the University of Freiburg. His teachers included Edmund Husserl and Martin Heidegger. Socialist theory was in the 1920s highly structuralist and mechanistic. Many thinkers assumed that capitalism would automatically collapse because of the tendency of the profit rate to fall and that socialism would automatically emanate from capitalism. In the world of social theory and philosophy, thinkers such as Herbert Marcuse and Günther Anders searched for alternatives that were oriented on concrete human praxis. In the 1920s, both thought that Heidegger's philosophy offered such an approach. When it became evident in the 1930s that the concrete political project that Heidegger supported was Nazism, Anders and Marcuse were among the scholars who turned against him and started realising the problematic elements in their former teacher's philosophy. "Certainly, never before has a reactionary doctrine put on such subversive clothes" ${ }^{33}$ (Anders 2001, 28).

Anders (2001) characterises Heidegger's philosophy as nihilistic existentialism because in it, "death is the lodestar of life and being is "being-toward-death"' 54 (Anders 2001, 49). For Heidegger, being is characterised by death and the circumstance that any concrete being (that Heidegger terms Da-sein) comes to its end: "Factically one's own Da-sein is always already dying, that is, it is in a beingtoward-its-end" (Heidegger 1996, 235). Anders also criticises that for Heidegger (2001, 202), not the human being, but Da-sein (being-there) is the subject.

For Heidegger, most being-there is inauthentic: "Factically, Da-sein maintains itself initially and for the most part in an inauthentic being-toward-death" (Heidegger 1996, 240). For Heidegger, being-there (Da-Sein, Seiendes) becomes authentic when one accepts the possibility of death so that death does not strike one as a surprise: "Authentic being-toward-death signifies an existentiell possibility of Da-sein" (240). "One's own potentiality-of-being becomes authentic and transparent in the understanding being-toward-death as the ownmost possibility" (283).

Anders argues that Heidegger leaves out the analysis of where alienation (that Heidegger refers to as Das Man [the they] or Uneigentlickeit [inauthenticity]) comes from and simply posits it as a priori. Heidegger does not see that "the 'they' that is being supplied with principles, opinions and feelings in the commodity form, is 'inauthentic' and 'dispossessed' of its own possibilities" ${ }^{55}$ (Anders 2001, 54). For Heideger,"the 'they' is not the result of a historical process, but an a priori 'who of Dasein'"56 (Anders 2001, 55). Heidegger ignored "the social struggles of his time" 57 (Anders 2001, 61). The "real powers that be, are not worthwhile mentioning in Heidegger's philosophy (Anders 1948, 354). Heidegger would not give attention to need, hunger, and capitalism: "For the fact however, that 'Dasein' is hungry, or, in more customary words, that men are hungry, we are looking in vain" (Anders 1948, 346). Although Heidegger talks about Sorge (concern, care), he does not concern himself with the "'Sorge-tools' of today, the economic systems, industry, machines"

\footnotetext{
${ }^{53}$ Translation from German: „Gewiß, noch nie hat sich eine reaktionäre Lehre ein so umstürzlerisches Gewand angetan“ (Anders 2001, 28).

${ }^{54}$ Translation from German: „[d]as Sterben wird zum Leitstern des Lebens, und das Dasein ein ,Sein zum Tode'“.

${ }^{55}$ Translation from German: „das ,man', beliefert mit warenartigen Prinzipien, Meinungen und Gefühlen, seiner eigenen Möglichkeiten ,enteignet' ist“.

${ }^{56}$ Translation from German: „Denn für ihn ist das ,man' kein Ergebnis eines geschichtlichen Verlaufs, sondern ein apriorisches ,Wer des Daseins'“.

${ }^{57}$ Translation from German: „die sozialen Kämpfe seiner Zeit“.
} 
(347). According to Anders, also Heidegger's concept of historicity (Geschichtlichkeit) is pseudo-concrete: "State, economy, slavery, law - nothing of it is so much as mentioned in Heidegger's philosophy of history. [...] The fact that the major portion of history is history of power, thus history of the un-free, history imposed upon people, is totally suppressed" (360).

Because of leaving out the political-economic context of society, Heidegger's concept of being is "a hopelessly amputated existence that cannot give answers to the true questions, i.e. the true difficulties of our existence, because it does not ask them" ${ }^{\prime 58}$ (Anders 2001, 50). "The reality of industrialisation, democracy, the width of the contemporary world, and the working class did not enter his philosophy because Heidegger is a provincial petty bourgeois" ${ }^{9}$ (42-43). "It is already Heidegger's fault that he only sees the 'they' as foil for the existence of the human being and that he does not see that it could be the task of the human being to create an authentic world that corresponds to the human being"60 (58).

Günther Anders' critique makes evident that Heidegger's philosophy leaves a theoretical void, namely the question of how the alienation of society, alienated human activity, and alienated technologies are grounded. Whereas critical theorists such as Georg Lukács, Herbert Marcuse and Günther Anders himself see alienation based on Marx's works grounded in class, capitalism and domination, these dimensions of heteronomous societies do not exist for Heidegger. Anders argues that this theoretical void made Heidegger unresisting to Nazi ideology. "Little wonder that he had no principle whatsoever, no social idea, in short: nothing, when the trumpet of National Socialism started blaring into his moral vacuum: he became a Nazi" (Anders 1948, 356).

The publication of Heidegger's (2014a, 2014b, 2014c, 2015) Black Notebooks shows that in his thought world, he filled the void by anti-Semitism (for a detailed discussion, see Fuchs 2015a, 2015b, Trawny 2016). For Heidegger, Jewishness is associated with instrumental reason: "Jewry's temporary increase in power is, however, grounded in the fact that Western metaphysics, especially in its modern development, furnishes the starting point for the diffusion of a generally empty rationality and calculative ability, which in this way provides a refuge in 'spirit', without being able grasp the hidden decision regions on their own. The more originary and primordial the prospective decisions and questions, the more they remain inaccessible to this 'race'" 61 (Heidegger 2014c, 46). Heidegger does not see

58 Translation from German: „ein hoffnungslose amputiertes Dasein, das die wirklichen Fragen, d.h. die wirklichen Schwierigkeiten unseres Daseins schon deshalb nicht beantworten kann, weil es sie gar nicht fragt".

${ }^{59}$ Translation from German: „Was nicht in seine Philosophie einging, war die Tatsache der Industrialisierung, der Demokratie, der Weite der heutigen Welt, der Arbeiterbewegung denn Heidegger ist provinzieller Mittelständler“.

${ }^{60}$ Translation from German: „Aber daß Heidegger allein das ,man’ als Folie für die Existenz des Menschen sieht; daß er nicht sieht, daß eine dem Menschen angemessene eigentliche Welt zu schaffen auch die Aufgabe des Menschen sein könnte - das ist eben bereits die Schuld Heideggers“ (Anders 2001, 58).

${ }^{61}$ Translation from German: „Die zeitweilige Machtsteigerung des Judentums aber hat darin ihren Grund, daß die Metaphysik des Abendlandes, zumal in ihrer neuzeitlichen Entfaltung, die Ansatzstelle bot für das Sichbreitmachen einer sonst leeren Rationalität und Rechenfähigkeit, die sich auf solchem Wege eine Unterkunft im ,Geist' verschaffte, ohne die verborgenen Entscheidungsbezirke von sich aus je fassen zu können. Je ursprünglicher und anfänglicher die künftigen Entscheidungen und Fragen werden, um so unzugänglicher bleiben sie dieser ,Rasse"'. 
instrumental reason as a principle of quantification associated with class rule and bureaucratic domination. Given that he filled his theoretical void with anti-Semitism, it is no surprise that Heidegger became a member of the Nazi-party.

Anders $(2001,275,70-71)$ sees parallels between Heidegger's and Hitler's thought, namely anti-humanism, anti-democratic affects, the doctrine of occupation, unscrupulousness, the metaphysics of death, and anti-civilising and anti-universalist ideology. "Both metaphysics simultaneously glorify and trivialise death. In Nazi metaphysics, this assumption takes on the form of education for war. War is seen as realising Germany's authentic Da-sein: 'We are born to die'. In existentialist philosophy, we find the transformation of death into 'being-toward-death' that allegedly is identical with authenticity" ${ }^{\prime \prime 2}(70)$. "These parallels show that the model of becoming-authentic is in both cases very similar"63 (71).

In contrast to Heidegger, Hegel's dialectic of master and slave is according to Anders much more concrete than Heidegger's philosophy (Anders 2001, 61). It does not conceive of existence as singularity, but as contradiction. "This is the reason why Hegel is still more topical than Heidegger. [...] Because the neutralisation of existence by positing Da-sein as singularity results in completely undialectical Dasein" 64 (61-62). "Being-without-dialectic" ${ }^{65}$ (62) would be a characteristic of Heidegger's philosophy. According to Anders, Marx in contrast to Heidegger in his Economic and Philosophic Manuscripts and The German Ideology understands that the worker's being is inauthentic because "as incarnated labour time, he is being-foranother and being-owned-by-another"66.

Pseudo-concreteness is for Günther Anders also a characteristic quality of Heidegger's concept of technology. For Heidegger, "not by staring at a hammer do we know what it is, but by hammering. [...] Are modern machines really 'revealing' themselves by their operation? Is their product their purpose? Is not their purpose to be seen only by making transparent much more than the machines themselves? [...] Operating a modern machine, does not reveal it at all; its 'alienation' is obviously reckoned with in present-day society and its division of labor. [...] that at the point where Heidegger seems to become 'concrete' or 'pragmatic', he is most obsolete, shows, so to speak, a machine-smashing attitude, for all his examples are taken from the provincial shoemaker workshop. The alienation produced precisely by those tools that are supposed to be revealing, is alien to him" (Anders 1948, 344).

Anders argues that for Heidegger, the world is a Zeug-world (a world of things and equipment) with hammer, nails and petty-bourgeois babble, a world that "resembles the rural shoemaker's workshop" ${ }^{\prime 67}$ (Anders 2001, 212). For Heidegger, technology is

\footnotetext{
62 Translation from German: „In beiden Metaphysiken wird der Tod zugleich verherrlicht und bagatellisiert; in der nationalsozialistischen durch Erziehung zum Kriege, der das eigentliche Dasein Deutschlands verwirkliche: ,Wir sind zum Sterben geboren'; in der ExistenzPhilosophie durch Verwandlung des Todes in das angeblich mit dem Eigentlichsein identische ,Sein zum Tode'“ (Anders 2001, 70).

${ }^{63}$ Translation from German: „Diese Parallelen zeigen, daß das Modell des Eigentlichwerdens in beiden Fällen sehr ähnlich ist“".

${ }^{64}$ Translation from German: „Deshalb ist Hegel noch immer aktueller als Heidegger. [...] Denn die Neutralisierung des Daseins im Singular hat zugleich zur Folge, daß das Dasein völlig undialektisch ist".

65 Translation from German: „Dialektiklosigkeit“.

${ }^{66}$ Translation from German: „weil er als fleischgewordene Arbeitszeit anderem Dasein zu eigen ist".

67 Translation from German: „der dörflichen Schusterwerkstatt ähnelt“.
} 
artisanal and agricultural (Anders 2001, 287). "He is not interested in machines" (Anders 2001, 258). Heidegger does not take into account that technologies serve "the profit need of the class that owns the means of production"69 (Anders 2001, 213).

In Being and Time, Heidegger (1996) mentions examples of Zeug, namely "writing, materials, pen, ink, paper, desk blotter, table, lamp, furniture, windows, doors, room", "hammering with the hammer," (64). "The shoe to be produced is for wearing (footgear), the clock is made for telling time" (65). Heidegger's analysis of technology is a romantic idealisation of pre-modern times, of a world without electricity that is dominated by rural life, agriculture and toil. Anders' analysis of technology in contrast engages with the technologies of his time in the context of capitalism and imperialism. Whereas Heidegger analyses technologies as such, Anders focuses on the mutual shaping of technologies and political economy. Anders therefore for example analyses television and radio in the context of capitalism and the atom bomb in the context of imperialism. Capitalism and imperialism do not exist in Heidegger's philosophy or his analysis of technology.

In those instances where Heidegger mentions modern technologies such as public transport and the newspaper, it becomes evident that he sees modernity and its technologies in general as inauthentic and "true dictatorship" (Heidegger 1996, 119). Heidegger's notion of being as being-without-dialectic results in a one-dimensional notion of technology that does not see any contradictions in the relationship of society and technology.

A truly Heideggerian analysis of the computer, the Internet, the digital and data rejects the computer as such. It disregards the potentials the computer has as a tool of co-ordination in a decentralised democratic socialist economy and society, and idealises handwriting, paper and pencils. But computing has in fact not outdated these technologies; rather, it has updated them. The computer brings a myriad of positive effects for the simplification of our everyday life. Problems emerge when instrumental reason shapes computing and society. When computing does not substitute, but supports human activities, then it can have humanising effects.

\section{Conclusion}

The philosophy of technology is very frequently associated with Martin Heidegger. The publication of Heidegger's Black Notebooks has made evident that his concept of rationality has anti-Semitic characteristics. Günther Anders stressed in his analysis of Heidegger that such problems and weaknesses have to do with the pseudoconcreteness of Heidegger's approach that leaves behind a theoretical gap and is blind to political economy.

Anders has in contrast and opposition to Heidegger elaborated a critical theory of technology. For Anders, technology is not simply a world of tools. Capitalism and imperialism are themselves world machines for the accumulation of capital and power that shape and are shaped by machines reciprocally. Anders allows us to critically analyse how the technological fetishism associated with the Promethean gap takes on new forms today, such as that of digital positivism, big data fetishism, or post-humanist ideology.

In his analysis of commercial television and radio, Anders stresses aspects of labour, ideology and their alternatives. Today, the users of social media are what

\footnotetext{
${ }^{68}$ Translation from German: „Maschinen interessieren inn nicht“.

69 Translation from German: „dem Profitbedürfnis der die Produktionsmittel besitzenden Klasse“.
} 
Anders termed homeworkers. Their use of platforms such as Google, YouTube and Facebook is digital labour that produces a big data commodity that is sold for enabling targeted advertising. The world of the Internet appears to have democratised communications, but it is today shaped by new power asymmetries in the online attention economy that features new forms of banalisation, unilateralism, di-vidualism, sensationalism, and anti-sensationalism.

Anders stresses that the interaction between technology, capitalism and imperialism generates annihilatory potentials. Given that capitalism and imperialism continue to exist and today tend to take on authoritarian forms, what Anders termed annihilism (annihilatory nihilism) remains a constant threat.

At the international level, Günther Anders' work has thus far remained rather undiscovered, which has to do with the fact that his principal work Die Antiquiertheit des Menschen is yet to be published in English. Anders' works reminds us that confronting the negative dialectics of contemporary society requires critical intellectuals and political praxis.

\section{References}

Anders, Günther. 2016. On Promethean Shame. In Prometheanism: Technology, Digital Culture and Human Obsolescence, Christopher John Müller, 29-95.

London: Rowman \& Littlefield International.

Anders, Günther. 2001. Über Heidegger. Munich: C. H. Beck.

Anders, Günther. 1982. Hiroshima is überall. Munich: C. H. Beck.

Anders, Günther. 1980a. Die Antiquiertheit des Menschen 2. Über die Zerstörung des Lebens im Zeitalter der dritten industriellen Revolution. Munich: C. H. Beck.

Anders, Günther. 1980b. The Obsolescence of Man, Volume II: On the Destruction of Life in the Epoch of the Third Industrial Revolution. Translated by Josep Monter Pérez.

https://libcom.org/files/ObsolescenceofManVol\%20IIGunther\%20Anders.pdf

Anders, Günther. 1964a. Wir Eichmannsöhne. Munich: C. H. Beck. $3^{\text {rd }}$ edition.

Anders, Günther. 1964b. We, Sons of Eichmann. Translation by Jordan Levinson, http://anticoncept.phpnet.us/eichmann.htm

Anders, Günther. 1962/2014. Theses for the Atomic Age. In The Life and Work of Günther Anders: Émigré, Iconoclast, Philosopher, Man of Letters, ed. Günter Bischof, Jason Dawsey and Bernhard Fetz, 187-194. Innsbruck: Studienverlag.

Anders, Günther. 1956. Die Antiquiertheit des Menschen 1: Über die Seele im Zeitalter der zweiten industriellen Revolution. Munich: C. H. Beck.

Anders, Günther. 1948. On the Pseudo-Concreteness of Heidegger's Philosophy. Philosophy and Phenomenological Research 8 (3): 337-371.

Arendt, Hannah. 1977. Eichmann in Jerusalem: A Report of the Banality of Evil. New York: Penguin Books.

Bryce, Emma. 2017. Cancer Vs. The Machine: How to Personalise Treatment Using Computing Power. Jasmine Fisher Is Reverse Engineering Cancer. Wired Online, March 9, 2017.

Eatherly, Claude and Günther Anders. 1962. Burning Conscience. New York: Monthly Review Press.

Fromm, Erich. 1942/2001. The Fear of Freedom. Abingdon: Routledge.

Fuchs, Christian. 2017a. Social Media: A Critical Introduction. London: Sage. $2^{\text {nd }}$ edition.

Fuchs, Christian. 2017b. Sustainability and Community Networks. Telematics and Informatics 34 (2): 628-639. 
Fuchs, Christian. 2016. Reading Marx in the Information Age: A Media and Communication Studies Perspective on Capital Volume I. New York: Routledge.

Fuchs, Christian. 2015a. Martin-Heidegger's Anti-Semitism: Philosophy of Technology and the Media in the Light of the "Black Notebooks". Implications for the Reception of Heidegger in Media and Communication Studies. tripleC: Communication, Capitalism \& Critique 13 (1): 55-78.

Fuchs, Christian. 2015b. Anti-Semitism, Anti-Marxism, and Technophobia: The Fourth Volume of Martin Heidegger's Black Notebooks (1942-1948). tripleC: Communication, Capitalism \& Critique 13 (1): 93-100.

Fuchs, Christian. 2012. Dallas Smythe Today - The Audience Commodity, the Digital Labour Debate, Marxist Political Economy and Critical Theory. Prolegomena to a Digital Labour Theory of Value. tripleC: Communication, Capitalism \& Critique 10 (2): 692-740.

Fuchs, Christian. 2002. Zu einigen Parallelen und Differenzen im Denken von Günther Anders und Herbert Macuse. In Geheimagent der Masseneremiten Günther Anders, ed. Dirk Röpcke and Raimund Bahr, 113-127. St. Wolfgang: Edition Art \& Science.

Heidegger, Martin. 2015. Anmerkungen I-V (Schwarze Hefte 1942-1948). Gesamtausgabe, Band 97. Frankfurt am Main: Klostermann.

Heidegger, Martin. 2014a. Gesamtausgabe, Band 94: Überlegungen II-VI (19311938). Frankfurt am Main: Klostermann.

Heidegger, Martin. 2014b. Gesamtausgabe, Band 95: Überlegungen VII-XI (1938/1939). Frankfurt am Main: Klostermann.

Heidegger, Martin. 2014c. Gesamtausgabe, Band 96: Überlegungen XII-XV (1939_ 1941). Frankfurt am Main: Klostermann.

Heidegger, Martin. 1996. Being and Time. Albany, NY: State University of New York Press.

Hesiod. 2006. Theogony. Works and Days. Testimonia. Cambridge, MA: Harvard University Press.

Kershner, Isabel. 2016. Pardon Plea by Adolf Eichmann, Nazi War Criminal, Is Made Public. New York Times Online, January 27, 2016.

Kollanyi, Bence, Philip N. Howard and Samuel C. Woolley. 2016. Bots and Automation over Twitter during the Third U.S. Presidential Debate. http://politicalbots.org/wp-content/uploads/2016/10/Data-Memo-Third-PresidentialDebate.pdf

Kraft, Daniel. 2017. Quantified Self to Quantified Health: How Tech Helps Doctors Fill Gaps in Patient Records. Wired Online, March 9, 2017.

Kurzweil, Raymond. 2005. The Singularity Is Near. London: Viking Penguin.

Liessmann, Konrad Paul. 2014. Between the Chairs: Günther Anders - Philosophy's Outsider. In The Life and Work of Günther Anders: Émigré, Iconoclast, Philosopher, Man of Letters, ed. Günter Bischof, Jason Dawsey and Bernhard Fetz, 73-82. Innsbruck: Studienverlag.

Liessmann, Konrad Paul. 2002. Günther Anders: Philosophieren im Zeitalter der technologischen Revolutionen. Munich: C. H. Beck.

Marcuse, Herbert. 1969. Repressive Tolerance. In A Critique of Pure Tolerance, 81123. Boston: Beacon Press.

Marcuse, Herbert. 1964. One-Dimensional Man. London: Routledge.

Molden, Berthold. 2014. Günther Anders as a Transnational Intellectual in the 1960s. In The Life and Work of Günther Anders: Émigré, Iconoclast, Philosopher, Man of 
Letters, ed. Günter Bischof, Jason Dawsey and Bernhard Fetz, 59-69. Innsbruck: Studienverlag.

Marx, Karl. 1867. Capital Volume I. London: Penguin.

Norris, Robert S. and Hans M. Kristensen. 2010. Global Nuclear Weapons Inventories, 1945-2010. Bulletin of the Atomic Scientists 66 (4): 77-83

Mayer-Schönberger, Viktor and Kenneth Cukier. 2013. Big data. A Revolution That Will transform How we Live, Work and Think. London: Murray.

Medeiros, João. 2016. Europe's Hottest Startups 2016: Paris. Wired Online, September 12, 2016.

Smythe, Dallas W. 1981. Dependency Road: Communications, Capitalism, Consciousness, and Canada. Norwood, NJ: Ablex.

Smythe, Dallas W. 1977. Communications: Blindspot of Western Marxism. Canadian Journal of Political and Social Theory 1 (3): 1-27.

Smythe, Dallas W. 1951. The Consumer's Stake in Radio and Television. The Quarterly of Film, Radio and Television 6 (2): 109-128.

Steadman, Ian. 2013. Big Data and the Death of the Theorist. Wired Online, January 25, 2013.

Stockholm International Peace Research Institute (SIPRI). 2016. Global Nuclear Weapons: Downsizing But Modernizing. https://www.sipri.org/media/pressrelease/2016/global-nuclear-weapons-downsizing-modernizing

Temperton, James. 2015. Bristol Is Making A Smart City For Actual Humans. Wired Online, March 17, 2015.

Tiffin, Richard. 2015. Boost Agriculture With Big Data. Wired Online, March 2, 2015.

Trawny, Peter. 2016. Heidegger \& the Myth of A Jewish World Conspiracy. Chicago, IL: University of Chicago Press.

\section{About the Author}

Christian Fuchs is a critical theorist. His research and writing focus on the analysis of capitalism, communication(s) and digital media. He is co-editor of tripleC:

Communication, Capitalism \& Critique. @fuchschristian http://fuchs.uti.at 